\title{
Carderock Mine Drop Experiment
}

\author{
K. Todd Holland \\ Naval Research Laboratory \\ Code 7440.3 \\ Stennis Space Center, MS 39529 \\ phone: (228) 688-5320 fax: (228) 688-4476 email: tholland@nrlssc.navy.mil.edu \\ Award Number: N0001402WX20650 \\ http://www7440.nrlssc.navy.mil/morphology/
}

\section{LONG-TERM GOALS}

Mine burial prediction begins with an estimate for the depth of burial resulting from mine impact with the bottom. Recent observations and models suggest that this depth is closely related to the characteristics of the mine flow through the water column. For example, impact angle and velocity are thought to be important parameters. The long term goal of research on this topic is to have the capability to estimate the range of mine fall trajectories and impact conditions that correspond to various mine drop scenarios.

\section{OBJECTIVES}

The objective of this effort was to collect data describing the fall of mine-shaped cylinders through the water column. Analysis and interpretation of these data were to be completed under separate efforts.

\section{APPROACH}

NRL staff designed and fabricated six 1/3-scale cylindrical mine shapes (figure 1) representing the range of foreign threat bottom mines, varying the bulk density, length-to-diameter ratio, location of the center of mass relative to the center of volume, and nose shape (blunt vs. hemispherical). Laboratory tests were conducted at the Explosion Test Pond, Naval Surface Warfare Center, Carderock Division, West Bethesda, Maryland during the week of Sept 10 2001. 1/3-rd scale models representative of prototype mines were used to gather a statistically representative data sample of trajectories. In coordination with NSWC personnel, a digital video recording system was designed for near real time data analysis to yield model trajectory and velocity during free-fall through the water column. 


\section{Report Documentation Page}

Form Approved

OMB No. 0704-0188

Public reporting burden for the collection of information is estimated to average 1 hour per response, including the time for reviewing instructions, searching existing data sources, gathering and maintaining the data needed, and completing and reviewing the collection of information. Send comments regarding this burden estimate or any other aspect of this collection of information,

including suggestions for reducing this burden, to Washington Headquarters Services, Directorate for Information Operations and Reports, 1215 Jefferson Davis Highway, Suite 1204, Arlington

VA 22202-4302. Respondents should be aware that notwithstanding any other provision of law, no person shall be subject to a penalty for failing to comply with a collection of information if it

does not display a currently valid OMB control number.

\begin{tabular}{|c|c|}
\hline $\begin{array}{l}\text { 1. REPORT DATE } \\
\mathbf{3 0} \text { SEP } 2002\end{array}$ & $\begin{array}{l}\text { 3. DATES COVERED } \\
\mathbf{0 0 - 0 0 - 2 0 0 2} \text { to 00-00-2002 }\end{array}$ \\
\hline \multirow{3}{*}{$\begin{array}{l}\text { 4. TITLE AND SUBTITLE } \\
\text { Carderock Mine Drop Experiment }\end{array}$} & 5a. CONTRACT NUMBER \\
\hline & 5b. GRANT NUMBER \\
\hline & 5c. PROGRAM ELEMENT NUMBER \\
\hline \multirow[t]{3}{*}{ 6. AUTHOR(S) } & 5d. PROJECT NUMBER \\
\hline & 5e. TASK NUMBER \\
\hline & 5f. WORK UNIT NUMBER \\
\hline $\begin{array}{l}\text { 7. PERFORMING ORGANIZATION NAME(S) AND ADDRESS(ES) } \\
\text { Naval Research Laboratory,,Code 7440.3,,Stennis Space } \\
\text { Center,,MS,39529 }\end{array}$ & $\begin{array}{l}\text { 8. PERFORMING ORGANIZATION } \\
\text { REPORT NUMBER }\end{array}$ \\
\hline \multirow[t]{2}{*}{ 9. SPONSORING/MONITORING AGENCY NAME(S) AND ADDRESS(ES) } & 10. SPONSOR/MONITOR'S ACRONYM(S) \\
\hline & $\begin{array}{l}\text { 11. SPONSOR/MONITOR'S REPORT } \\
\text { NUMBER(S) }\end{array}$ \\
\hline
\end{tabular}

12. DISTRIBUTION/AVAILABILITY STATEMENT

Approved for public release; distribution unlimited

13. SUPPLEMENTARY NOTES

14. ABSTRACT

Mine burial prediction begins with an estimate for the depth of burial resulting from mine impact with the bottom. Recent observations and models suggest that this depth is closely related to the characteristics of the mine flow through the water column. For example, impact angle and velocity are thought to be important parameters. The long term goal of research on this topic is to have the capability to estimate the range of mine fall trajectories and impact conditions that correspond to various mine drop scenarios.

15. SUBJECT TERMS

16. SECURITY CLASSIFICATION OF:

a. REPORT

unclassified b. ABSTRACT unclassified c. THIS PAGE unclassified
17. LIMITATION OF ABSTRACT

Same as

Report (SAR)
18. NUMBER

OF PAGES

5 19a. NAME OF

RESPONSIBLE PERSON 


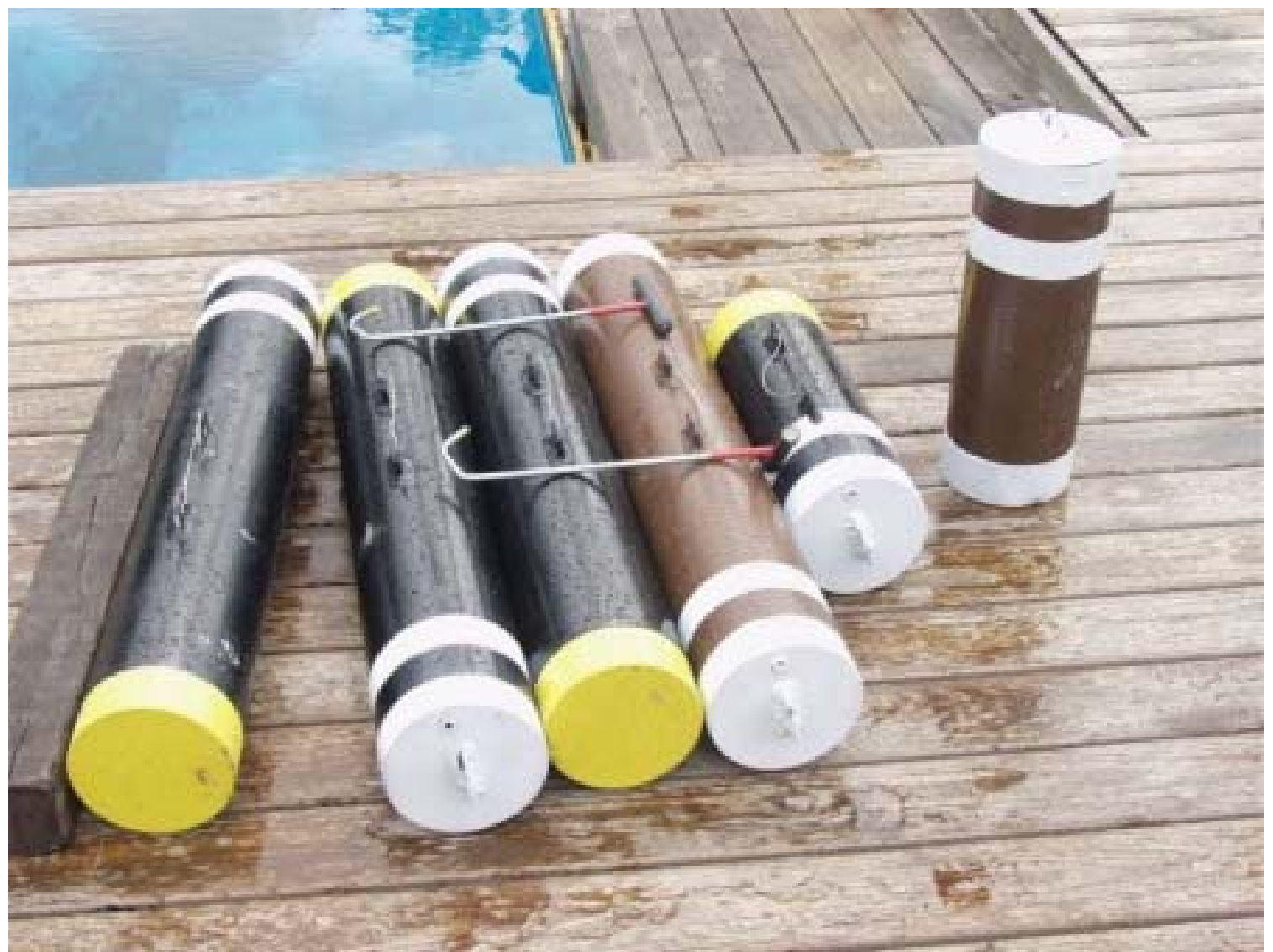

Figure 1. Typical one-third scale mine cases.

A total of 203 drops of the six models were conducted; 75 were released in the air while 128 were released from a totally submerged position. Models were released from orientations of long axis horizontal; long axis vertical, nose down; and intermediate orientations of $\sim 30^{\circ}$ to $45^{\circ}$ nose down. Of the total drops, more than 190 resulted in digital imagery of sufficient quality for automated data processing producing position and time for two or more points on the model body during fall through the water column. These $\mathrm{x}, \mathrm{y}, \mathrm{z}, \mathrm{t}$ data sets were then processed to yield model trajectory, velocity, pitch and azimuth (relative to heading at launch). An example is shown in Figure 2. 
File 12a-2.out (Air Drop) - Length: $50.5 \mathrm{~cm}$, Mass: $22.2 \mathrm{~kg}$

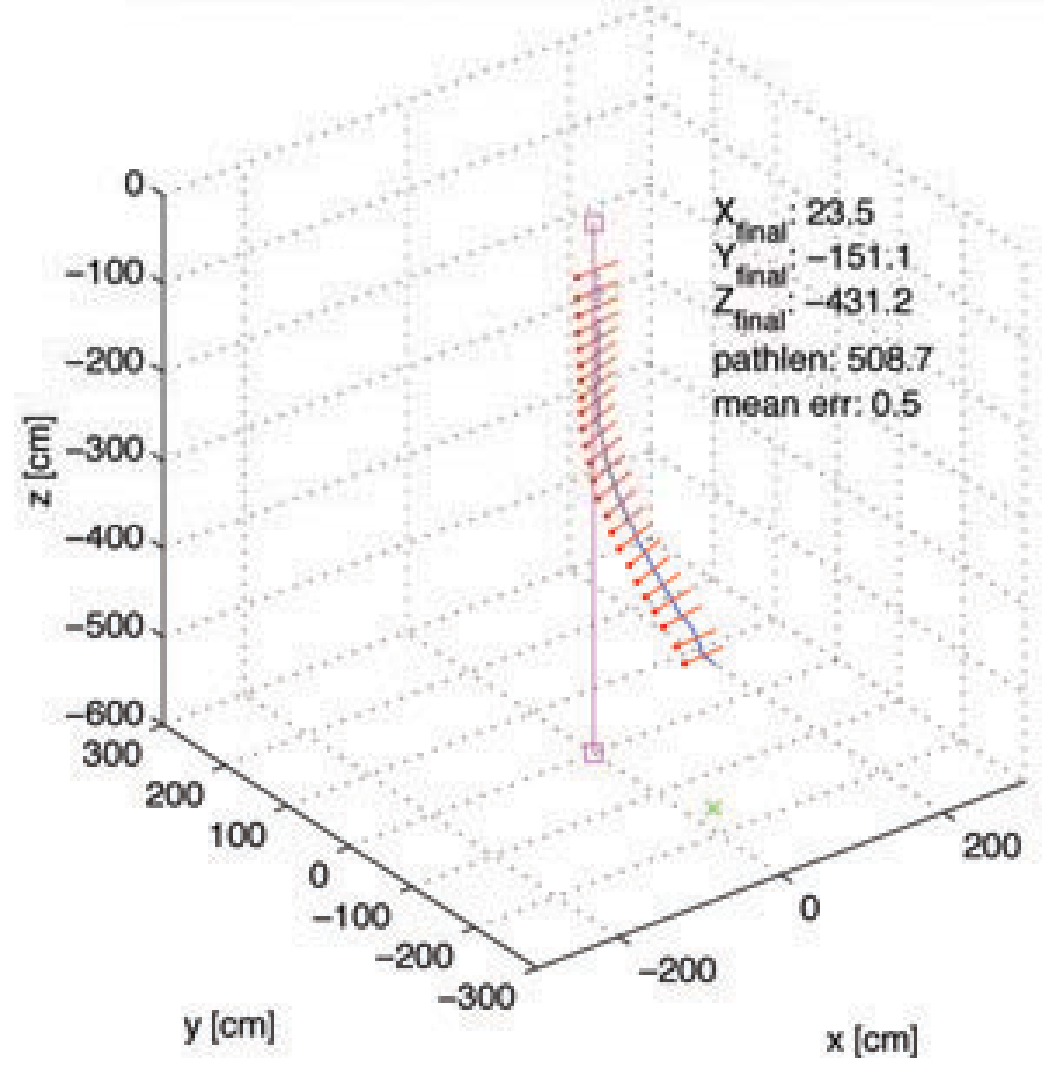

Figure 2. Example of mine fall trajectory and orientation.

\section{WORK COMPLETED}

Tests were successfully conducted in a professional manner despite the anxiety surrounding world events that week.

\section{RESULTS}

Although detailed interpretation was outside the scope of this effort, some important results were found. Observations of model behavior indicate: (1) when the center of mass (CM) is located near the center of volume $(\mathrm{CV})$, i.e., $(\mathrm{CM}-\mathrm{CV}) /($ mine length $)<0.05$, then there is a strong tendency for cylinders in free-fall to orient with maximum area presented to the direction of relative flow; (2) for cylinders released in air, trailing air bubbles in the water column dampen boundary layer effects on the cylinder; and (3) with loss of trailing air bubbles, boundary layer effects generate a wide range of motion and lateral excursion for the cylinder. 


\section{IMPACT/APPLICATIONS}

Since few quality observations of mine fall behavior had been previously made, these measurements are crucial in extending our understanding of the possible range in impact conditions that can be expected for impact burial.

\section{TRANSITIONS}

The data collected during this study will be used as ground truth for hydrodynamic models developed at the Naval Postgraduate School and at MIT. In addition, the ranges of behaviors are being parameterized for use in an expert systems approach to impact burial modeling.

\section{RELATED PROJECTS}

This effort is closely related to field studies of impact burial being conducted by the Naval Research Laboratory and the Office of Naval Research. 